Ann. Biol. anim. Bioch. Biophys., I968, 8 (2), 217-224.

\title{
DNA CONTENT OF SPERMATOZOA IN FERTILE AND INFERTILE BULLS, AND ERRORS IN ITS DETERMINATION
}

\author{
M.-F. KRAMER \\ with technical assistance of Ankie WrLlEmsen and Rosalie JANssen \\ Department of Histology, \\ Faculty of Medicine, \\ State University of Utrecht (The Netherlands)
}

\section{SOMMAIRE}

La teneur moyenne en ADN des spermatozoïdes de Taureau (Dsp) est $3.28 \times$ Io $^{-6} \mu \mathrm{g}$ (S. $\mathrm{E} .=0.056 ; 42$ éjaculats ; 5 taureaux). Il n'a pas été trouvé de différences significatives entre 3 taureaux de fécondance normale.

La cause principale de la variabilité des teneurs individuelles (S. D. = II.I p. I00) se situe dans la détermination du nombre de spermatozoïdes (S. D. $=6.7-10.0$ p. 100).

$\mathrm{Ni}$ la conservation à $4^{\circ} \mathrm{C}$, ni la congélation suivie par la décongélation ne provoquent de modification de la teneur moyenne des spermatozoïdes en ADN.

Les Dsp, mesurées sur 22 éjaculats de 7 taureaux avec une fertilité réduite ou une stérilité, se trouvent toutes dans le champ des valeurs normales, les moyennes par taureau ne diffèrent pas significativement de la valeur moyenne normale.

La littérature sur la Dsp, déterminée soit par la biochimie, soit par la cytophotométrie, est discutée : une déviation ou altération de la Dsp n'a pas encore été démontrée dans des cas de fertilité réduite.

\section{INTRODUCTION}

Biochemical data on the DNA content of bull spermatozoa (table I) reveal rather great differences in value. Except for one study, the estimation of measuring errors has been given no attention, therefore we thought it worthwhile to make another attempt at determining the DNA content per bull spermatozoon (Dsp) taking into account possible errors in determination.

We were able to extend our observations to a number of apparently normal ejaculates from healthy, but infertile bulls, 


\section{TABLEAU I}

$D N A$ content per bull spermatozoon, in $\mu g \cdot 10^{-\mathbf{B}}$, as cited in the literature. Teneur en ADN $\left(\mu \mathrm{g} \cdot 10^{-6}\right)$ par spermatozoide de taureau, donnée dans la litterature

\begin{tabular}{c|l}
\hline Zittle, O'Dell (1941) & 4.52 \\
Vendrely, Vendrely (1948) & 3.30 \\
Mirsky, Ris (1949) & 2.82 \\
Bhargava et al. (1959) & 3.38 (bull $\left.\mathrm{N}_{1}: 3.34 ; \mathrm{N}_{1}: 3.43\right)$ \\
Summerhill, OLds (1961) & $2,95( \pm 0.17)(n=71)$ \\
\hline
\end{tabular}

\section{MATERIAL}

42 normal ejaculates from 5 normal bulls with proven fertility (The Utrecht Centre of Artificial Insemination) were stored at $4^{\circ} \mathrm{C}$. Within 34 hours the spermatozoa were washed, counted and their DNA content determined.

The effect of the storage of ejaculates on Dsp was determined by measuring 9 ejaculates - from 2 healthy, fertile bulls - before and after storage for 2 to 8 days in a milk-egg yolk dilution (used for artificial insemination) at $4^{\circ} \mathrm{C}$.

The influence of freezing $\left(a t-20^{\circ} \mathrm{C}\right)$ and thawing on fresh, undiluted ejaculates was determined in the same way in 4 ejaculates of one bull.

Finally DNA was determined in 22 ejaculates from 7 normal bulls with proven low fertility or sterility, but without any symptom of disease. The general characteristics of these ejaculates were entirely normal. Some of the samples used were fresh (within 34 hours after ejaculation); others had been frozen and stored for several months when measured. Services.

Table 2 gives the data on these bulls which were obtained from the Provincial Animal Health

\section{TABLEAU 2}

Age, semen quality and fertilization rate of 7 bulls with sterility or low fertility Age, qualité du sperme et niveau de fécondance de 7 taureaux stériles ou subfertiles

\begin{tabular}{|c|c|c|c|c|}
\hline Bull & $\begin{array}{l}\text { Age } \\
\text { (years) }\end{array}$ & $\begin{array}{l}\text { Semen } \\
\text { quality }\end{array}$ & Use & Per cent fertilization rate \\
\hline $\begin{array}{l}N \ldots \ldots \ldots \\
R B \ldots \ldots \\
J H \ldots \ldots \\
K B 58 \ldots \ldots\end{array}$ & $\begin{array}{l}1 \\
7 \\
8 \\
1\end{array}$ & $\begin{array}{l}\text { excellent } \\
\text { good } \\
\text { good } \\
\text { good }\end{array}$ & $\begin{array}{l}\text { artificial } \\
\text { insemination }\end{array}$ & 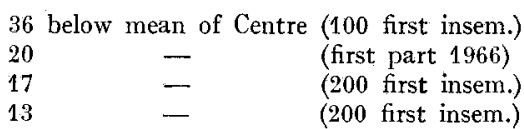 \\
\hline $\begin{array}{l}V \ldots \ldots \\
S c h \ldots \ldots \\
G K 3 \ldots \ldots\end{array}$ & & $\begin{array}{l}\text { good } \\
\text { moderate } \\
\text { good }\end{array}$ & $\begin{array}{l}\text { natural service } \\
\text { on farms with } \\
\text { otherwise } \\
\text { normal fertility }\end{array}$ & $\begin{array}{l}0 \text { (20 first services) } \\
0 \text { (25 first services) } \\
0 \text { (16 first services) }\end{array}$ \\
\hline
\end{tabular}

\section{ME'THODS}

A washed suspension (containing from 40 to $400 \cdot 10^{6}$ spermatozoa per ml) from each of the ejaculates was prepared by triple centrifugation and resuspension in physiological saline.

Each suspension was counted in four hæmocytometers, each of which was filled from another dilution pipette (dilution : $\mathrm{I}$ : 100, with 2.5 per cent T-pol in saline). The four counting chambers 
and pipettes were used in random combinations to prevent the introduction of a systematic error. The result of the four countings was used as an estimate of the actual number. The standard deviation of these estimates varied from 6.7 to Io.o per cent, as calculated with the equation of CHAMBERLAIN and TURNER (1952). This equation takes into account the influence of deviations in the size of the chambers and pipettes. The more of this material used the less deviatory influence there is, hence we counted four chambers filled with four pipettes at random. If the number of chambers and pipettes is constant, the error of the count varies with the number of spermatozoa counted. A count of 300 spermatozoa has a calculated error of 7.3 per cent. (Using 24 chambers and pipettes per ejaculate, we found that the actual standard deviation of a counting with four chambers and pipettes amounts to a percentage not exceeding the value calculated with the aid of the equation.)

Four samples of $0.5 \mathrm{ml}$ were taken from each suspension for DNA determination. The spermatozoa were extracted twice with $0.5 \mathrm{~N}$ perchloric acid during I $_{5}$ minutes at $70^{\circ} \mathrm{C}$. A third extraction did not increase the DNA yield. The quantity of DNA in the two pooled extracts was determined with diphenylamine-acetaldehyde (BURTON, 1956). The mean result of the four samples was used as an estimate of the DNA content in the suspension. The standard deviations of these means varied from 0.5 to 3.9 per cent, with a mode of $r .1$ per cent.

We did not remove the free nucleotides with cold perchloric acid prior to extraction at $70^{\circ} \mathrm{C}$ (which dissolves some DNA), because the pool of free nucleotides in bull spermatozoa is only 4 per cent of DNA weight (BHARGAVA et al., I959).

As a reference we used a standard solution of DNA (Sigma, type $x$, sodium salt, from calf thymus) in I N NaOH, diluted with distilled water to a final concentration of about $300 \mu \mathrm{g} \mathrm{per} \mathrm{ml.}$ The purity of this preparation was found to be 80.16 per cent $(\mathrm{S}$. $\mathrm{E} .=0.37)$ as determined by ultraviolet spectrophotometry (SPIRIN, I958). DNA determinations using the diphenylamine-acetaldehyde method (BURTON) were performed on aliquots of the standard diluted with $0.5 \mathrm{~N}$ perchloric acid after heating at $70^{\circ} \mathrm{C}$ for 15 minutes.

\section{RESULTS}

I2 series of DNA determinations using diphenylamine-acetaldehyde on 4 different dilutions of the standard DNA solution (corrected for 19.84 per cent impurity) gave a linear relation between DNA content (D) per $\mathrm{ml}$ and extinction (E) in a $\mathrm{I} \mathrm{cm}$ cell at $600 \mathrm{~nm}$ :

$$
\mathrm{D}=88.27( \pm 0.47)(*) \cdot \mathrm{E}_{600}^{1} \mathrm{~cm}
$$

Measurements on 42 suspensions of bull spermatozoa showed the relationship between extinction (E) at $600 \mathrm{~nm}$ and the number of extracted spermatozoa (N) per ml extract to be :

$$
\mathrm{IO}^{9} \cdot \mathrm{E}_{600}^{\mathrm{I} \mathrm{cm}}=37 . \mathrm{II}( \pm 0.63)(*) \cdot \mathrm{N}
$$

The quantity of DNA per spermatozoon (Dsp) is calculated by dividing the determined DNA content (D) in I $\mathrm{ml}$ extract by the number of spermatozoa (N) from which the DNA is extracted:

$$
\text { Dsp }=\frac{\mathrm{D}}{\mathrm{N}}=88.27( \pm 0.47)\left({ }^{*}\right) \cdot \frac{\mathrm{E}_{600}^{1 \mathrm{~cm}}}{\mathrm{~N}} \mu \mathrm{g}
$$

A combination of the equations (3) and (2) yields :

$$
\text { Dsp }=3.28( \pm 0.06)\left({ }^{*}\right) \cdot 10^{-6} \mu \mathrm{g}
$$

This and other results are shown in table 3. Dsp differences in the three bulls are not significant. We were not able to find a change in the measured Dsp either after storage at $4^{\circ} \mathrm{C}$ for several days, or after freezing and thawing (table 4 ).

$\left({ }^{*}\right)$ Standard error of the mean. 


\section{TABI,EAU 3}

Mean DNA content per spermatozoon (Dsp) for all 5 fertile bulls, and for 3 of them individually Teneur moyenne en ADN par spermatozoïde (Dsp) de 5 taureaux fertiles et de 3 d'entre eux individuellement

\begin{tabular}{|c|c|c|c|}
\hline \multicolumn{2}{|c|}{ Ejaculates } & \multirow{2}{*}{$\underset{\left(\mu g \cdot 10^{-6}\right)}{\text { Dsp }} \pm$ S. E. } & \multirow{2}{*}{$\begin{array}{l}\text { S. D. of individual } \\
\text { determinations } \\
\text { in } \% \text { of Dsp }\end{array}$} \\
\hline Bull & Number & & \\
\hline All bulls. & 42 & $3.28 \pm 0.06$ & 11.1 \\
\hline Atto...... & 16 & $3.39 \pm 0.08$ & 9.8 \\
\hline$W G, \ldots \ldots \ldots \ldots$ & 13 & $3.18 \pm 0.08$ & 9.5 \\
\hline Dorus.............. & 9 & $3.34 \pm 0.15$ & 13.2 \\
\hline
\end{tabular}

TABLEAU 4

Influence of storage at $4^{\circ} C$ ( 2 to 8 days), and of freezing and thawing on the mean DNA content per spermatozoon (Dsp)

Effet de la conservation à $4^{\circ} C$ (de 2 à 8 jours) et de la congélation suivie de décongélation sur la teneur moyenne en $A D N$ par spermatozoïde (Dsp)

\begin{tabular}{|c|c|c|c|c|}
\hline \multirow{2}{*}{ Bull } & \multirow{2}{*}{$\begin{array}{c}\text { Number } \\
\text { of ejaculates }\end{array}$} & \multirow{2}{*}{ Treatment } & \multicolumn{2}{|c|}{$\begin{array}{l}\text { Dsp (mean and S. E.) } \\
\mu \mathrm{g} \cdot 10^{-6}\end{array}$} \\
\hline & & & untreated & treated \\
\hline Alto & 5 & $\begin{array}{c}\text { fresh } \\
\text { stored }\left(+4^{\circ} \mathrm{C}\right)\end{array}$ & $3.38(0.17)$ & $3.28(0.09)$ \\
\hline$W G$ & 4 & $\begin{array}{c}\text { fresh } \\
\text { stored }\left(+4^{\circ} \mathrm{C}\right)\end{array}$ & $3.25(0.12)$ & $3.23(0.18)$ \\
\hline Fr & $\begin{array}{l}6 \\
4\end{array}$ & $\begin{array}{c}\text { fresh } \\
\text { frozen }\left(-20^{\circ} \mathrm{C}\right)\end{array}$ & $3.17(0.12)$ & $3.25(0.02)$ \\
\hline
\end{tabular}


Dsp values found in the 22 ejaculations of bulls with sterility or low fertility did not exceed the range between I. 7 standard deviations on either side of the mean value of the normal bulls, nor did the mean value per bull (when more than 3 ejaculates per bull were available) differ significantly from the value of normal bulls. These results are shown in table 5. Of course, small deviations may still be hidden in the error of the determinations, because of the small number of the latter.

TABLEAU 5

Mean DNA content per spermatozoon (Dsp) for 7 bulls with low fertility or sterility. Teneur moyenne en $A D N$ par spermatozoide (Dsp) de 7 tauraux subfertiles ou stériles.

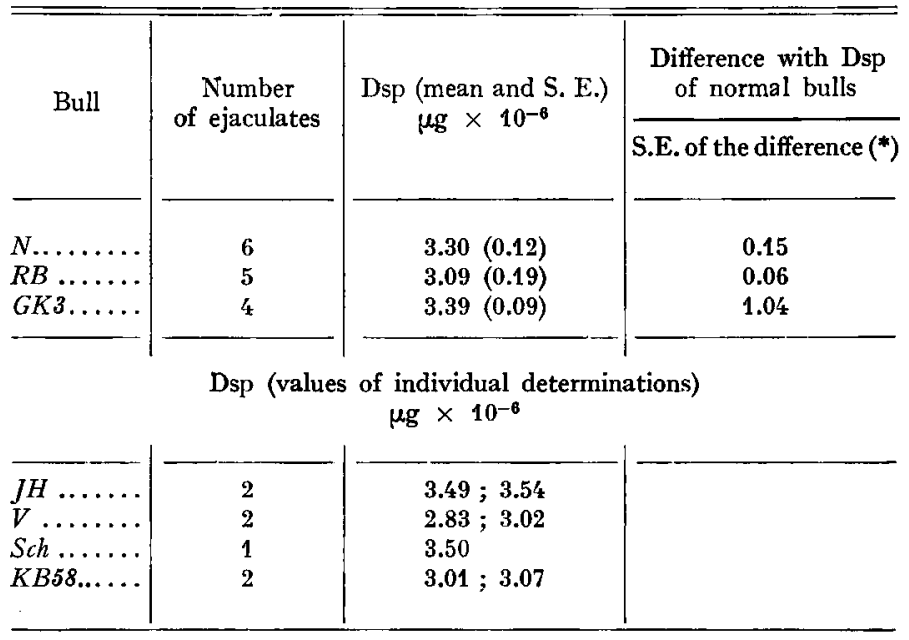

$\left(^{*}\right)=\sqrt{(\text { S. E. of normal bulls })^{2}+\text { (S. E. of abnormal bulls) }^{2}}$.

\section{DISCUSSION}

The exactness of Dsp absolute value depends on the exactness of the determination of DNA content in the standard solution using SpIRIN's ultraviolet method (I958), and on the validity of the equation, given by the same author, for the DNA of calf thymus.

Our results are quite in agreement with those of VENDREI,Y and VENDRELY (I948) and Bhargava et al. (I959). The former have applied the diphenylamineacetaldehyde method, calculating DNA quantity on the assumption that $d$-ribose accounts for 40 per cent of DNA weight. The latter have measured ultraviolet absorption and based their calculation of DNA quantity on a given extinction coefficient assumed to be valid for any kind of DNA.

The lower value found by SUmmerhILL, and OLDS (I96I) may be ascribed to the use of $\mathrm{NaOH}$ in extracting spermatozoan DNA. VENDRFLY and VENDRELY (I948) already mentioned the defectiveness of this method for spermatozoa, yeasts, and bacteria. 
Using other methods than biochemical determination (table I), some authors have estimated Dsp with ultraviolet cytophotometry and have found values of $2.8 \times \mathrm{IO}^{-6} \mu \mathrm{g}$ (LEUCHTENBERGER and VENDRELY, I952), $3.9 \times \mathrm{IO}^{-6} \mu \mathrm{g}$ (WAL,KER and YATES, I953) and $3.24 \times 10^{-6} \mu \mathrm{g}$ (SANDRITTER et al., I960). With Feulgen photometry a value of $3.04 \times 10^{-6} \mu \mathrm{g}$ has been calculated (LEUCHTENBERGER et al., I956 a).

The standard deviation of individual Dsp determinations per ejaculate is II.I per cent (table 3 ). This is only a little higher than 6.7 to ro.o per cent standard deviation of the counting results. Apparently, the latter are the main source of error in Dsp determinations. If only those determinations are selected, the spermatozoa countings of which were performed with a calculated error below 8.0 per cent $(4$ chambers, 4 pipettes and more than 280 spermatozoa counted), the standard deviation of individual Dsp determinations per ejaculate decrease to 8.2 per cent. This also illustrates the high degree of Dsp error caused by error in the counting. The error of Dsp determinations per ejaculate by SuMmLRmIL, and OLDS (I96r) amounts to 48.6 per cent, but no information concerning their counting method has been given.

Storage nor freezing and thawing noticeably change measured Dsp values. The results are quite in agreement with the findings of Törö and POSALAKY (I959), who stated that even after 2 weeks of storage at $37^{\circ} \mathrm{C}$ no change in Feulgen stainability of spermatozoa is observed. On the other hand, SALISBURy et al. (Ig6r) found a 24 per cent decrease of apparent Dsp (measured with Feulgen cytophotometry) in bull spermatozoa after 2-day storage. In the light of the results of GLEDHILL et al. (I966 c), and BouTERs et al. (1967) (who found changes in apparent Feulgen DNA content in spermatozoa while the ultraviolet determinations did not show any difference) the results of SAIISBURY et al. (I96I) are not contradictory with ours. Changes in sensibility for acid hydrolysis or in stain permeability during the storage of the spermatozoa are the possible causes of a decreased Feulgen stainability without an actual decrease in DNA content.

Since LEUCHTENBERGER et al. (I953) estimated cytophotometrically on Feulgen stained spermatozoa Dsp differences between fertile and infertile men, other investigations have confirmed such a relation; for men (LEUCHTENBERGER et al., I955, I956 $b$; WEIR and LEUCHTENBERGER, I957) ; for bulls (LEUCHTENBERGER, I956 a and I956 $c$; PAREz et al., I960). SUMMERHILI and OLDS (I96I) have calculated a significant correlation $(=+0,43)$ between Dsp and fertility of the ejaculates within bulls.

In applying ultraviolet cytophotometry, GLEDHILL et al. (I966 $a$ and b) were not able to confirm this for several infertile bulls, although they observed differences in Feulgen DNA content; neither do our results show measurable differences in the Dsp of a number of ejaculates from bulls with proven sterility or low fertility as compared with normal bulls.

In all these investigations infertile ejaculates with otherwise normal characteristics are used ; in other words there was no apparent cause of infertility. Although our results and those of GLEDHIL, et al. (I966 $a$ and $b$ ) may not be generalized, somewhat deviatory Dsp values are not yet proven to play a role in this type of infertility.

If small deviations of normal Dsp occur, they can only be found with certainty 
by ultraviolet cytophotometry because of its low error of mean (I.5 per cent) (BouTERs et al., I967). A biochemical approach, with a ro per cent error, detects abnormal values only if the deviation from normal is large, or if a great number of determinations can be made. It has the added disadvantage of not giving information on the distribution of Dsp within the spermatozoa of one ejaculate. An abnormal distribution with a normal mean cannot be detected by a biochemical determination, yet it could very well be related to low fertility or sterility.

\section{Rę̧u pour publication en décembre 1967 .}

\section{SUMMARY}

The mean DNA content per bull spermatozoon (Dsp) is $3.28 \times{ }_{10}^{-6} \mu \mathrm{g}$ (S. E. $=0.05^{6}$; 42 ejaculates ; 5 bulls). There are no significant differences between the Dsp of 3 bulls with normal fertility.

The main source of variability in individual determinations (S. D. = II.I per cent) is in the error of spermatozoa counting (S. D. =6.7-I0.0 per cent).

Neither storage at $4^{\circ} \mathrm{C}$ nor freezing and thawing significantly alter the Dsp.

In 22 ejaculates from 7 bulls with sterility of low fertility Dsp values fall within the normal range, the mean per bull not differing significantly from the mean Dsp in normal bulls.

The literature on biochemically or cytophotometrically determined Dsp is discussed. It is concluded that deviations or changes in Dsp have not yet been demonstrated, and that they have not been proven to occur in cases of lowered fertility.

\section{ACKNOWLEDGMENT}

I am much indebted to Drs. G. J. M. Th. Tonino and Th. H. RozIJN for their biochemical advice, and to Prof. M. T. JANSEn and Mr. C. J. Van DuiJn Jr. for their critical reading of this text.

\section{REFERENCES}

Bhargava P. M., Bishop M. W. H., WORK T. S., I959. The chemical composition of bull semen with special reference to nucleic acids, free nucleotides and free amino acids. Biochem. J., 73, 242-247.

Bouters R., Esnault C., Ortavant R., Salisbury G. W., 1967. Comparison of DNA, revealed by feulgen and by ultra-violet light in rabbit spermatozoa after storage in the male efferent ducts. Nature, $213,5072,18 \mathrm{I}-\mathrm{I} 82$.

Burton K., I956. A study of the conditions and mechanism of the diphenylamine reaction for the colorimetric estimation of DNA. Biochem. J., 62, 315-322.

Chamberlain A. C., Turner M., 1952, Errors and variations in white-cell counts. Biometrics, 8, 55-60.

GLEDHILL B. L., I966a. Studies on the DNA content, dry mass and optical area of ejaculated spermatozoal heads from bulls with normal and lowered fertility. Act. vet. scand., 7, 166-1 73 .

Gledhill B. L., Gledhill M. P., Rigler R., Ringertz N. R., I966 b. Atypical changes of DNP during spermatogenesis associated with a case of infertility in the bull. J. Reprod. Fert., 12, 575-578.

Gledhill B. L., GledHill M. P., Rigter R., Ringertz N. R., Ig66 $\epsilon$. Changes in DNP during spermiogenesis in the bull. Exp. Cell Res., 41, 652-665.

Leuchtenberger C., Leuchtenberger R., Vendrely C., Vendrely R., I952. The quantitative estimation of DNA in isolated individual animal nuclei by the Caspersson ultra-violet method. Exp. Cell Res., 3, 240-244.

Leuchtenberger C., Schrader F., Weir D. R., Gentile D. P., i953. The DNA content in spermatozoa of fertile and infertile human males. Chromosoma, 6, 61-78. 
Leuchtenberger C., Weir D. R., Schrader F., Murmanis L., i955. The desoxyribose nucleic acid (DNA) content in spermatozoa of repeated seminal fluids from fertile and infertile men. J. Lab. Clin. Med., 45, 85I-864.

Leuchtenberger C., Murmanis I., Murmanis L., Ito S., Weir D. R., I956 a. Interferometric dry mass and microspectrophotometric arginine determinations on bull sperm nuclei with normal and abnormal DNA content. Chromosoma, 8, 73-86.

Leuchtenberger C., Leuchtenberger R., Schrader F., Weir D. R., I956 b. Reduced amounts of desoxyribonucleic acid in testicular germ cells of infertile men with active spermatogenesis. Lab. Invest., $5,422-440$.

Leuchtengberer C., Schrader F., Hughes-Schrader S., Gregory P. W., i956 c. Certain cytochemical and cytological aspects of dwarfism in cattle. J. of Morphol., 99, 48I-5I 2 .

MiRSky A. E., Ris H., I949. Variable and constant components of chromosomes. Nature, 163, 666-667.

Parez M., Petel J. P., Vendrely C., ig6o. Sur la teneur désoxyribonucléique des spermatozoïdes de taureaux présentants différents degrés de fécondité. C. R. Acad. Sci., 251, $25^{81-2583 .}$

Salisbury G. W., Birge W. J., Torre L. de la, Lodge J. R., I96r. Decrease in nuclear Feulgenpositive material (DNA) upon aging in in vitro storage of bovine spermatozoa. J. B. B. Cyt., 10, 353-359.

SANDRITTER R., MÜLlER D., GENSECKE O., I.960. Ultraviolettmikrospectrophotometrische Messungen des Nukleinsäuregehaltes von Spermiën und diploiden Zellen. Acta Histochem., 10, 139-154.

SPIRIN A. S., I958. Spectrophotometric determination of total nucleic acid content. Biokhimiya, 23, 656-67I.

SUMMERHILl W. R., OLDS D., I961. Levels of deoxyribonucleic acid in bovine spermatozoa and their relationship to fertility. J. Dairy Sci., 44, 548-55I.

Törö I., Pósalaky Z., I959. Histochemische Untersuchung der Spermiogenese. Acta Histochem., 8, 393-405.

VENDRELY R., VENDRELY C., I948. La teneur du noyau cellulaire en acide desoxyribonucléique à travers les organes, les individus et les espèces animales. Experientia, 4, 434-436.

Walker P. M. B., Yates H. B., I953. Nuclear components of dividing cells. Proc. Royal Soc. London, $B, 140,274^{-299}$.

Weir D. R., Leuchtenberger C., I957. Low sperm desoxyribose nucleic acid as possible cause for otherwise unexplained human infertility. Fert. Steril., 8, 373-378.

ZitTle Ch. A., O'dell R. A., I96i. Chemical studies of bull spermatozoa. J. Biol. Chem. 140, 899-907. 